Herausgeber

Dr. habil. Michael Brzoska, Internationales Konversionszentrum Bonn (BICC)

Prof. Dr. Hans J. Giessmann, Institut für Friedensforschung und Sicherheitspolitik an der Universität Hamburg

Dr. Heiner Hänggi, Genfer Zentrum für die demokratische Kontrolle der Streitkräfte (DCAF), Genf

Kapitän zur See Heinz-Dieter Jopp, Führungsakademie der Bundeswehr, Hamburg

Dr. Erwin Müller, Chefredakteur Andreas Prüfert, Europäische Organisation der Militärverbände (EUROMIL), Brüssel

\section{Schriftleitung}

Prof. Dr. Hans J. Giessmann

\section{Redaktion}

Dr. Erwin Müller (V.i.S.d.P.)

Dr. Patricia Schneider

Dr. Thorsten Stodiek

\section{Beirat}

Dr. Alyson Bailes, Stockholm International Peace Research Institute (SIPRI), Stockholm

Dr. Detlef Bald, München

Prof. Dr. Joachim Betz, Universität, Hamburg

Prof. Dr. Hans-Peter Dürr, Träger

des Alternativen Nobelpreises, München
Prof. Dr. Pál Dunay, Genfer Zentrum für Sicherheitspolitik, Genf Prof. Dr. Wolfgang Gessenharter, Helmut-Schmidt-Universität, Hamburg

Dr. Sabine Jaberg, Führungsakademie der Bundeswehr, Hamburg

Prof. Dr. Charles A. Kupchan, Georgetown University, Washington, D.C.

Dr. Martin Kutz, Führungsakademie der Bundeswehr, Hamburg

Dr. Krzysztof Ruchniewicz, WillyBrandt-Zentrum für Deutschland- und Europastudien, Wroclaw
Dr. Martina Fischer, Berghof Forschungszentrum für Konstruktive Konfliktbearbeitung, Berlin

\title{
Human Security: An Idea Whose Time Has Come?
}

\author{
Keith Krause*
}

\begin{abstract}
This article outlines the origins of »human security « as a concept stemming from the policy-making community. By advocating a narrow vision of human security revolving around the notion of »freedom from fear « - a perspective emphasizing that human development cannot be advanced without attention to basic security needs - the article asserts that the use of the concept of human security by states and decision-makers is not merely a trivial matter of labelling. Rather, it leads states and policy-makers to focus on different issues, to ask different questions, and even to promote different policies, developments that have a significant impact in shaping at least some parts of the international security agenda for the $21^{\text {st }}$ century.
\end{abstract}

Keywords: Menschliche Sicherheit, menschliche Entwicklung, staatliche Sicherheit, Freiheit von Furcht.

$\mathrm{T}$ The concept of »human security « widely used by a wide range of governments, international organizations and non-governmental organizations (NGOs), is only the latest in a long series of attempts to challenge traditional state-centred conceptions of security. These include such ideas as global security, societal security, common se-

\footnotetext{
* Dr. Keith Krause is Professor of Political Science at the Graduate Institute of International Studies, Geneva, Director of the Institute's Programme for Strategic and International Security Studies (PSIS), and Programme Director of the Small Arms Survey. - An earlier draft of this article was presented at the Bonn International Center for Conversion's (BICC) 10th Anniversary Conference »Promoting Security: But How and For Whom? «, 1-2 April 2004, Bonn, Germany. The article also draws upon an earlier publication, »Une approche critique de la sécurité humaine », in Jean-François Rioux (ed.), La sécurité humaine, Paris 2002, pp. 73-98.
}

curity, comprehensive security and cooperative security. ${ }^{1}$ Aside from being the most recent of these attempts to reformulate or redefine the concept of security, the human security approach is significant because policy-makers have adopted the discourse of human security, and have used it to generate important and interesting foreign and security

1 See, for a few of the key texts, the Independent Commission on Disarmament and Security Issues (the Palme Commission), Common Security: A Blueprint for Survival, New York 1982; Ashton Carter, William Perry and John Steinbrunner, A New Concept of Cooperative Security, Washington 1992; David Dewitt, "Common, Comprehensive and Cooperative Security, " The Pacific Review, 7(1), 1994, pp. 1-15; Barry Buzan, People, States and Fear, second edition, Hemel Hempstead, 1991; Ole Waever, "Societal Security - A Concept and its Consequences«, unpublished paper, 1995; The Report of the Commission on Global Governance, Our Global Neighbourhood, Oxford 1995, pp. 80-81. 
policy initiatives. So is human security an idea whose time has come?

To answer this question, one first needs to accept that all concepts of security - including the so-called traditional concept of »national security« - are social constructs. This is not difficult to demonstrate. Before the Cold War, »the term 'national security' was not common in American political discourse $\ll^{2}$ (or in that of any other state). It was only in 1945, in the US Senate hearings on the post-World War II American defence policy and military structure, that Secretary of Defence James Forrestal invoked the idea of national security as a guiding principle for US policy. It was a new idea - you can hardly find the term being used before that time. Senator Edwin Johnson - an influential foreign policy advocate - replied, simply, »I like your words 'national security ${ }^{3}{ }^{3}$

\section{As the historian Daniel H. Yergin has noted:}

»At certain moments, unfamiliar phrases suddenly become common articles of political discourse, and the concepts they represent become so embedded in the national consciousness that they seem always to have been with us. So it was for the phrase 'national security' in 1945 ... its sudden popularity resulted from the fact that it encapsulated an outlook on the world, a mentality. « ${ }^{4}$

From this point on, it was treated as the conventional or mainstream concept of security, with its entailments of protection from and defence against the risk of war and largescale violence inflicted from outside of the political community. Yet this concept of security was largely a $20^{\text {th }}$ century construction and was tied to the Cold War in important ways. ${ }^{5}$

Arguably, the concept of human security is entering international discourse in much the same way. Like all concepts of security, its meaning is constructed through the various efforts of institutions and individuals, and in today's world, it is a powerful concept around which practical policies and concrete initiatives have been, and can be, developed and promoted.

This article explores the strengths, and some of the weaknesses, of the concept of human security, firstly by briefly discussing its genesis and the two different visions of human security that are in circulation. As part of this analysis, it will examine how human security relates to the concepts of human development and state security, and then try - in a very general way - to situate the concept more broadly within ideas about how states should relate to their citizens. Overall, the article argues that the use of the concept of human security by states and decisions-makers is not a trivial matter of labelling, and that the promotion of human security is not just a conceptual or theoretical issue. It leads states and policy-makers to focus on different issues, to ask different questions, and even to promote different

2 Daniel H. Yergin, Shattered Peace: The Origins of the Cold War and the National Security State, Boston, 1978, p. 194.

3 Ibid.

4 Ibid., p. 195.

5 See Ole Waever, »Security: A Conceptual History for International Relations «, unpublished paper, 1999. policies, developments that have a significant impact in shaping at least some parts of the international security agenda for the $21^{\text {st }}$ century.

\section{The Origins and Diffusion of Human Security}

The most striking thing about the concept of human security is that it was born in the policy world, and did not spring forth from either academics or analysts. It was first used in a serious way in the 1994 United Nations Development Programme (UNDP) Human Development Report. The UNDP vision of human security was very broad: it encompassed seven different dimensions, including economic, food, health, environmental, personal, community and political security. The overall goal was to expand the concept of security, which had »for too long been interpreted narrowly: as security of territory from external aggression, or as protection of national interests in foreign policy or as global security from the threat of nuclear holocaust «. Human security was thus meant to change the referent object of security »from an exclusive stress on territorial security to a much greater stress on people's security«, and, somewhat more problematically, to advocate »security through sustainable human development. $\ll^{6}$

The idea behind the UNDP report was that putting an emphasis on human security would make it possible to capture the so-called "peace dividend " and to ensure that the resources devoted to the military through the Cold War were directed towards more productive ends. The direct aim of the 1994 Human Development Report was to influence the outcome of the 1995 Copenhagen Social Summit, and from the outset the concept of human security was thus a practical one with clear strategic goals.

From the mid-1990s until today, the concept of human security has been used by a vast array of non-governmental or international organizations, including Oxfam, the UN High Commissioner for Refugees, the Academic Council on the UN System, the UN University, the Arias Foundation, the Center for Defence Information, the Worldwatch Institute, the Commission on Global Governance, the Carnegie Commission on Preventing Deadly Conflict, the International Action Network on Small Arms, Pax Christi, the Secretary-General of the United Nations, Harvard University's Program on Humanitarian Policy and Conflict Research, the Human Security Center at the University of British Columbia, Saferworld, the Bonn International Center for Conversion, the Center for Humanitarian Dialogue (Geneva), the Regional Human Security Center (Amman), the Canadian Consortium on Human Security, and so on. Of course, these groups and institutions were attracted to the idea because "human security « was a nice slogan. But there was more to it than that: human security was a lens, a way of describing or framing what they were doing that allowed a number of disparate policy initiatives to be linked, and to be given greater coherence.

6 United Nations Development Programme, Human Development Report 1994, New York 1994, pp. 22-46, at 22 and 24. 
In other words, the concept of human security was helping to catalyze a broader reframing of the parallel discourses of »security« and »development . In particular, by shifting the referent object of »security « from that of the state to that of the individual, it highlighted the tension that exists between promoting state security, and promoting the security of individuals (which has historically often been jeopardized by the state). Ultimately, the influence of such an idea cannot be measured simply by its use, however, but by whether or not it informs, or is linked to, a set of concrete practices that are either new, or that represent a significant departure from previous practices. In the case of human security, there were at least two specific important political initiatives that emerged in the late 1990s, which represented a partial departure from existing »ways of doing business «. Below I will detail some of the concrete policy initiatives that have also emerged.

The first political initiative, spearheaded by Canada, was the creation of the Human Security Network. It was established in 1999 as a loose grouping of states led by Canada, Norway and Switzerland, and including Chile, Jordan, Austria, Ireland, Mali, Greece, Slovakia, Thailand, South Africa (as an observer), and the Netherlands, who had as a goal pursuing common policies on human security in a variety of international and regional institutions. They meet annually at the Foreign Minister level, and throughout the year pursue their initiatives in a variety of formal and informal ways, as a forum for the coordination and shaping of the international security agenda. ${ }^{7}$ As a result, many of the member states, in particular the three leading states have also devoted significant financial resources to promoting human security initiatives, often hand-in-hand with non-governmental organizations or with other member states of the Network.

The second initiative was led by Japan, which had created a Trust Fund for Human Security as early as 1999. It subsequently established the Japanese-led Commission on Human Security, which was co-chaired by the former UN High Commissioner for Refugees, Dr. Sadako Ogata, and the Nobel prize winning economist, Professor Amartya K. Sen. ${ }^{8}$ Its report entitled Human Security Now was published in 2003, and it spawned the creation of a Human Security Advisory Board. The Trust Fund for Human Security itself supports initiatives led by institutions within the United Nations system.

On the practical level, the concept of human security was also used by a wide range of non-governmental or international organizations to give a new dynamism and emphasis to projects at the grassroots level. For these groups, a focus on human security meant - in the words of one advocate - »putting people first $« .{ }^{9}$ It meant adopting a bottom-up or local approach to security that focused on the relationship between states and their citizens, and that moved away from equating the security of a state or regime with

7 See the Network's website at http://www.humansecuritynetwork.org for a good survey of ongoing activities.

8 See the Commission's website at http://www.humansecurity-chs.org.

9 This phrase has been used to describe the small arms-related activities of the Geneva-based Centre for Humanitarian Dialogue. the economic, political and social well-being of the citizens. In most parts of the world, the state or regime was secured at the expense of the needs of its citizens - or worse: the state itself posed the most important threat to human security.

\section{Two Visions of Human Security}

There were, however, two competing visions of human security that emerged out of these various initiatives, and which are loosely reflected in the Japanese and Canadian initiatives. The first, broad, "Japanese vision drew upon the original UNDP formulation, and could be summarized by the phrase »freedom from want « - human security was about ensuring basic human needs in economic, health, food, social, and environmental terms. It was directly reflected in the 2003 report of the Commission on Human Security, and in the funding activities of the Japanese Trust Fund for Human Security. The Commission report focused not just on situations of conflict, but also on issues of fair trade, access to health care, patent rights, access to education, and basic freedoms, while the Trust Fund has sponsored projects in areas as diverse as food security for farmers in East Timor or fishermen in Southern Sudan, health security in Tajikistan or Mongolia, or the rebuilding of schools in Kosovo.

The second, more tightly focused, vision was linked more closely to the activities of the Human Security Network, and its key slogan was »freedom from fear « - human security was about removing the use of, or threat of, force and violence from people's everyday lives. I will offer examples of its policy initiatives below.

My own position on this is that human security ought to be about "freedom from fear «, and not about this broad vision of »freedom from want «, for two reasons. The first reason is a negative one: the broad vision of human security is ultimately nothing more than a shopping list; it involves labelling as threats to human security a wide range of issues that have no necessary link to each other, and at a certain point, human security seems to capture almost everything that could be considered a threat to well-being. It falls into the trap that Daniel H. Deudney aptly describes: »if everything that causes a reduction in human well-being is labeled a security threat, the term loses any analytical usefulness and becomes a loose synonym of 'bad'. «10

At this point, the concept loses all utility to policy makers and incidentally to analysts - since it obscures what is distinctive about the idea of »security «, and how it is inextricably tied up with conflict and existential threats, and the use of violence. Perhaps even more importantly, it is not clear that anything is gained by putting the label »human security « on issues such as the right to education, fair trade practices, or public health challenges. Does it change our

10 Daniel H. Deudney, »Environmental Security: A Critique«, in Daniel H. Deudney and Richard A. Matthew (eds.), Contested Grounds: Security and Conflict in the New Environmental Politics, Albany, 1999, pp. 187-219, at 192. 
understanding of the right to basic education when we describe illiteracy as a threat to human security - does it facilitate more effective action, does it help us solve problems? Or does it actually lead us down the wrong path in some cases, to treating certain problems, such as migration or HIV/AIDS, as threats to security, when they would better be considered as simple public policy challenges? The extensive literature on the "securitization « of migration illustrates this well. ${ }^{11}$ From a security perspective, Western European states (and certain elements of the European political elite) have often reacted to migration as if it posed a threat to societal identity and values. From an economic perspective, however, the overwhelming consensus is that Europe needs to encourage migration in order to sustain its welfare entitlements (including pensions), in the face of an aging workforce and population. The securitization of migration well illustrates some of the negative consequences of using the powerful concept of security in a loose, even perhaps politically careless, fashion.

On the other hand, if the concept of human security remains focused on »freedom from fear « - from the threat or use of violence - it can be linked to a powerful and coherent practical and intellectual agenda, that is embedded in a particular understanding of the liberal state. The question of controlling the institutions of organized violence and evacuating force from political, economic and social life has been central to the whole modern understanding of politics and the struggle to establish legitimate and representative political institutions. It is part of Thomas Hobbes' vision of the political Leviathan - an institution created to bring us out of the situation of »war of each against all « into a civil state in which economic, social and political life could flourish. It is echoed in Max Weber's definition of the state as an organization that has the legal monopoly over the legitimate means of violence. And it is tied up with the centuries-long struggle to eliminate the threat of force and violence from everyday human interactions.

\section{The Practical Agenda of Human Security}

When one moves off the definitional heights and down to the ground of policy-makers and activists, the idea of human security - in its narrow form of »freedom from fear « has given rise to a concrete agenda for political action. It includes a range of issues such as:

- Eliminating the scourge of anti-personnel landmines;

- Stopping the use of child soldiers and implementing effective demobilization and reintegration programmes for them;

- Ending the tradition of impunity by promoting respect for international humanitarian law (IHL) and the work of the International Criminal Court;

11 See, for representative contributions, Didier Bigo, "Sécurité et immigration: vers une gouvernementalité par l'inquiétude «, cultures et conflits, 3132 (automne-hiver 1998), pp. 13-38; Jef Huysmans, »The European Union and the Securitization of Migration «, Journal of Common Market Studies, 38(5), December 2000, pp. 751-777.
- Combating proliferation and misuse of small arms and light weapons;

- Working towards security-sector reform, including not just the armed forces, but the police and criminal justice system; and,

- Promoting good governance in the security sector.

This is a wide-ranging and ambitious agenda, and it is impossible to summarize all of the initiatives that have been pursued under these headings in recent years. There are, however, some important observations to be made about how issues emerged or were placed on the human security agenda. Firstly, the development of the »freedom from fear « agenda was ad hoc, and based on the experience of middlepower states working together (and occasionally in partnership with NGOs), in particular on the international campaign to ban anti-personnel landmines. The Ottawa Treaty is the hallmark of the human security approach, since it is difficult to conceive of this initiative emerging as long as one remains locked-in to a state-centric concept of security. But international action to ban landmines began in the early 1990s, and it was only after the Ottawa Treaty was concluded in 1997 that the whole exercise was labelled as an attempt to promote human security. ${ }^{12}$

Secondly, the states that came to the human security agenda did so in many cases with their own »baggage« of policies that they wished to promote. For example, Switzerland encouraged its traditional emphasis on IHL as part of the activities of the Human Security Network, Japan folded many of its established development assistance policies under the banner of human security, Austria pushed (for a time) human rights education as a human security issue, Canada pushed the issue of child soldiers after the landmines treaty was completed, and a whole host of states (most prominently Switzerland, Canada and Norway) seized the issue of small arms and light weapons proliferation, as the logical follow-on to the landmines issue. Political entrepreneurship by states, NGOs and international organizations was a crucial feature of the rapid development of the concept and practice of human security.

It would be a mistake, however, to consider that the crystallization of the concept of human security was a sort of afterthought or that its use as a label to describe policies that states were already pursuing makes the concept itself irrelevant. In fact, most important concepts in international politics (such as sovereignty, diplomacy, international law) emerge as a result of changes in state practice, and the recognition that disparate threads of policy and practice constitute a new 'form' that requires a specific label. The important question to ask therefore is: how does what states are »doing « today depart from conventional understandings of the international security agenda of ten or twenty years ago? Seen in this light, the issues that come under the heading of human security were almost completely absent from the international scene twenty years ago.

\footnotetext{
12 Two indispensable sources on land mines are: Maxwell Cameron, To Walk without Fear, Toronto 1998; and Richard Price, »Reversing the Gun Sights: Transnational Civil Society Targets Land Mines «, International Or-
} ganization, 52(3), Summer 1998, pp. 613-644. 


\section{Human Security and Human Development}

Another way to examine the merits of the broad versus narrow concepts of human security is to unpack the relationship between human security and human development. Arguably, »development « and "security" have been the two main pillars of contemporary multilateral action since 1945. Yet one could generalize, without being totally unfair, that for almost four decades ideas about development and security were completely disconnected and were pursued in parallel institutional and political structures. Entire institutions were built up to promote both security and development. People in the British, Canadian, Swiss, Swedish, Dutch or German development cooperation agencies hardly spoke to the counterparts in foreign and defence ministries, and the gap in institutional cultures remains enormous.

Debates on how to achieve development were thus effectively insulated (with some exceptions) from any considerations of security issues, for basically three reasons. Firstly, throughout the Cold War security policy was deemed an issue of national sovereignty, and thus matters such as defence or military spending were outside of the scrutiny of aid donors or international financial institutions. Secondly, security policies were often caught up in Cold War conflicts and alliances, and thus a taboo subject for development agencies or institutions. Thirdly, external scrutiny of a state's policies and practices towards its own citizens was deemed to be interference in the internal affairs of a state. The result was that development agencies and international financial institutions, at least until the early 1990s, excluded national security concerns from their mandates. In addition, it was widely believed in economic and development circles that development was a precondition for security, and that increased economic development would almost automatically reduce the incidence of conflict within, and potentially even between, states. It was not surprising that the UNDP 1994 formulation of human security focused on promoting »security through sustainable human development $\ll^{13}$

But on the ground things were not so simple, because ideas of security and development could not be so easily separated, and because the development-security link was not one-way. Economic development alone turned out not to be a recipe for eliminating or reducing conflict. For the international development community in the early 1990s, Rwanda was a success story - high levels of multilateral ODA were coupled with rapid progress in a variety of economic and social indicators. But the 1994 genocide starkly demonstrated that something was terribly, terribly wrong with this picture, and that a focus on economic development without attention to basic security concerns and needs, would not by itself resolve underlying conflicts and insecurities. More practically, a failure to pay specific attention to conflict and insecurities was likely to lead to waste, as waves of conflict or violence could wipe out whatever gains had been made in health care, education or infrastructure.

13 UNDP, Human Development Report 1994, New York 1994, p. 24.
With the rise in attention concerning intra-state and communal conflicts in the 1990s, it was almost inevitable therefore that the link between development and security be re-examined. Three noteworthy examples of this shift in thinking would be the concept of "security first « (that development efforts should first ensure that security exists or can be created), the idea of »sustainable disarmament for sustainable development «, and the focus on »security sector reform « by major aid donors and international financial institutions. These kinds of efforts represent a sea change in thinking in the international development community, whose importance cannot be overstated. ${ }^{14}$

In this environment, it was not surprising both that the concept of human security would land on fertile ground in some sectors of the development community and that it would encounter some conceptual fuzziness, as more »conservative « elements attempted to co-opt the concept without altering in any way the practice of development policy. From the perspective of human security (narrowly defined), you cannot achieve sustainable human development without human security - you cannot achieve »freedom from want « without achieving »freedom from fear«. In some cases, we perhaps therefore need to pursue the "security first « doctrine, and in all cases we need to recognize that we cannot advance far on promoting human development without attention to basic security needs.

\section{Human Security and State Security}

Many states, especially in the South, have regarded the concept of human security as a thin justification for a new form of interventionism, as a means of pitting citizens against their states. There is some truth to this, at least in the sense that the language of human security has been used to combat the culture of impunity and to strengthen civil society institutions and NGOs. It is also clear that there was a link between the Canadian promotion of human security (under the then Foreign Minister Lloyd Axworthy) and the creation of the Canadian-sponsored International Commission on Intervention and State Sovereignty (ICISS), which published its impressive report, The Responsibility to Protect, in $2001{ }^{15}$ This report was an attempt to rethink the idea of humanitarian intervention within the framework of human security, and it ultimately adopted a cautious approach to the circumstances in which it could be considered.

But a somewhat stronger point is that one should not be too impressed by what state elites say about human security, because one of the main sources of threat to people's security around the world undoubtedly comes from the state

\footnotetext{
14 The »security first « approach has been promoted by the EU in the context of the small arms debate; the second example was the title of a major international conference sponsored in October 1998 by the Belgian Ministry of Development Cooperation; the third has been the focus of numerous efforts, including that of the British Department for International Development (DFID) and the Development Assistance Committee (DAC) of the OECD

15 ICISS, The Responsibility to Protect: Report of the International Commission on Intervention and State Sovereignty, Ottawa 2001.
} 
- from corrupt police and judges, from violent and unruly gangs of ex-combatants, from predatory rulers who ignore basic rights and rule of law. As the ICISS put it, the international community may not have a right to intervene, but it should have a responsibility to protect the weak and vulnerable members of any community, especially from the threats of large-scale violence and genocide.

Paradoxically, most of the issues on the agenda of human security actually involve strengthening the role and resources of the state. Most of the activities around securitysector governance, or around stemming the proliferation and misuse of small arms, and other such issues, focus on the national level, and involve working with state authorities. But the goal is of course to reshape the relationship between states and their citizens, and to make the legitimacy and sovereignty of states conditional on how they treat their citizens. In a sense, promoting human security is about making states and their rulers keep their side of the basic social contract: states are created (among other things) to provide security - in order that individuals can pursue their lives in peace. States have responsibility not just to provide for welfare, or representation, but - first and foremost - to ensure the security of their citizens. This is the basic »compact « or contract that led humanity out of the Hobbesian anarchy.

\section{Conclusion}

Although human security may be a good idea whose time has come, this does not make it immune to critical scrutiny. Three main issues can be raised here. Firstly, and as noted above, there is a paradox in the promotion of policies that can lead to a strengthening of the state at the same time as the state is diagnosed as the source of much human insecurity. Disarming the weak without controlling the strong, for example, will not enhance human security in the long run. Encouraging good governance with lower military spending may actually, in some cases, leave a state prey to lawlessness and anarchy. Of course the goal is to contribute to the construction of strong and legitimate states, but the potential dilemmas or unanticipated consequences that human security policies may trigger must be recognized.

Secondly, the fact that much of the conceptualization of human security, and the elaboration of concrete policy initiatives, has emerged from states, rather than from civil society, poses a problem. States inevitably face systemic and competitive pressures that lead them to revert to more traditional foreign and security policy stances when they are perceived as »getting too far ahead « of the broader international community. Within every foreign policy bureaucracy there are traditionalists alongside the policy entrepreneurs and the balance shifts between them, depending on the perceived advantages and disadvantages that either approach gives to the state (or its Minister of Foreign Affairs). This sort of bureaucratic pulling and hauling is not surprising, but it can undermine the commitment to promoting the real concerns of human security. Certainly in Canada and Norway, two of the progenitors of the Human Security Network, traditionalists have at different points reasserted their weight against the enthusiasts for human security.

The third problem relates to the role of civil society and non-state actors in the practice of human security. In order for freedom from fear to be achieved, individuals have to be empowered to take control of their environment and to become stakeholders in political, economic and social processes that affect them. Yet associating a number of prominent Western scholars or NGOs with the idea of human security, and soliciting their input on a variety of policy questions, is not in itself going to advance this 'bottom-up' process of social change. Obviously, a more inclusive dialogue between states and civil society is desirable, but in the realm of human security, as in so many other realms, this 'new multilateralism' does not penetrate deeply, nor is it necessarily the case that non-governmental actors are equal contributors or partners. ${ }^{16}$ It is still the case that the people to whom »freedom from fear « matters are mostly passive subjects in the human security discourse.

Ultimately though, promoting an agenda of human security - promoting »freedom from fear « - draws our attention to a number of essential challenges around the world. It goes well beyond the traditional conflict prevention or conflict resolution agenda, and leads us to ask some basic questions about how to make people safe and secure in their daily lives - in their homes and streets, within their communities, and in their regions. It also shines a spotlight on the links between violence and insecurity, and underdevelopment and poverty, and perhaps can help give new direction or energy to some parts of the development community. For political actors and activists, human security is an excellent mobilizing slogan. It gives coherence to a set of policy issues that urgently need to be addressed, including the problems of post-conflict reintegration, the situation of vulnerable groups in conflicts, the role of small arms and light weapons in both war and non-war situations, and the effective and legitimate operation of the institutions that we have built to provide security and safety in the modern state.

More than that, it provides an intellectually strong foundation for innovative and focused policy initiatives. The contemporary promotion of human security is the culmination of the liberal project of building strong, legitimate and representative political institutions. It has its roots in enlightenment ideas of the importance of individual rights and personal freedoms. And if the $20^{\text {th }}$ century can be characterized as the century of the "national security state «, perhaps the $21^{\text {st }}$ will unfold under the sign of human security.

\footnotetext{
16 For a trenchant critique see Alejandro Bendaña, »Politics or Paternalism? The Need for a Social Transformation Framework in Global Campaigns: A View from the South «, unpublished paper posted at http://www.iansa. org/documents/research/res_archive/ngo29.htm\#1.
} 